\title{
Analysis on the Current Situation and Strengthening Ways of University Students' Political Identity in the Post-pandemic Era
}

\author{
Li Jianping ${ }^{1}$ \\ ${ }^{1}$ School of Public Affairs and Administration, University of Electronic Science and Technology of China \\ *Corresponding author. Email: ljp199707@163.com
}

\begin{abstract}
In the post-pandemic era, the Chinese government's powerful governance efficiency makes university students generally enhance national self-confidence. However, at present, the global epidemic will continue to spread, the reality of racial discrimination, xenophobia and other often leads to cyber violence. The majority of university students generally have a high sense of political identity, but there are also problems of not paying enough attention to ideological and political courses and not high political literacy. Therefore, the first measure is to enhance the effective state governance for strengthening the sense of the political identity of university students; second, innovate ideological and political education for university students; the third is to improve the political literacy of university students. The purpose of this paper is to provide some intellectual support for strengthening university students' sense of political identity.
\end{abstract}

Keywords: post-pandemic era, university students, political identity, strengthening way

\section{PREFACE}

Now our country has entered the "post-pandemic era," that is, the epidemic basically controlled as the node, human will enter a new era. This era is characterized by increased reaction speed to COVID-19 and increased awareness of epidemic prevention and control. In China, novel coronavirus pneumonia was released in April 29, 2020 in the white paper issued by the Information Office of the State Council. After the year of April 29, 2020, the epidemic prevention and control in China entered a normal stage [1]. We can take this as the time node and regard the time after that as the post-pandemic era. now the Cold War mentality of the West, through various online media channels, promotes hatred of China. The thinking of "I can, you cannot" threaten to curb China's development. Many lawbreakers also take the opportunity to propagate harmful news. How to improve the ability of information screening and political identity of university students, as well as reducing the network correct political information transmission distortion, is a very important ideological education problem that our country now faces.

Before the outbreak of novel coronavirus pneumonia, the younger generation of intellectuals was more influenced by the western strong cultural knowledge and discourse system. What they believed and felt was more western mainstream media bias. Many overseas Chinese students can often see their negative comments on their motherland after going abroad, such as "the air in Australia is so sweet, there is a strange luxury". It is hard to imagine that after going abroad, after the previous compulsory ideological and political education, students who have lived in China for so many years would slander their motherland like this. After this hot event, many people praised their motherland on their social media. However, it is difficult for us to change the influence of this event on international public opinion and even on some uninformed netizens. They believed and felt more slanted reports from the western mainstream media. However, China in the face of the epidemic test, from the CPC Central Committee to the grassroots, unified command, rapid response, in March on the rapid restoration of the national normal economic life order. This is a laudable example around the world. We have truly achieved respect for human rights and for life. For the students studying abroad, our country arranged the special plane to organize them to return home, give them "health kits", with practical action to feel the strength of the motherland, feel the motherland will always be their strongest support, enhance the sense of trust in the national government. For university students in China, 
our country has taken the measures of suspending classes in the early days and encouraging the implementation of online teaching. They have also felt the care of our policies and enhanced our own national confidence. Now this is the post-pandemic era. the world is amid "changes unseen in a century". That means there is a sea of unimaginable situations and the international situation will become more complex in this era. In responding to such a situation, it requires us university students to strengthen our political beliefs, understand the state's major policies, adhere to the thought of socialism with Chinese characteristics, with strong patriotic feelings, and strive to build a strong socialist country.

\section{THE CONNOTATION OF UNIVERSITY STUDENTS' SENSE OF POLITICAL IDENTITY}

Political identity is people's trust and belief in the political system, that is, the recognition, support and obedience to the state, political institutions, political systems, political processes, political consciousness and political authority. Political identity is a state of political participation in which people accept psychologically and actively participate in, maintain and promote the development of political system. Therefore, the political identity of university students refers to the identity of the national political system and the attention to national politics from the emotional level and verbal action. Nowadays, the increasingly changing and severe international situation requires our university students to establish a strong sense of political identity [2]. Understand the state's major policies, adhere to the thought of socialism with Chinese characteristics, with strong patriotic feelings, and strive to build a strong socialist country.

\section{THE PRESENT SITUATION OF UNIVERSITY STUDENTS' POLITICAL IDENTITY}

\subsection{University Students Generally Have A High Degree Of Political And Ideological Identity After The Epidemic}

According to the survey reality, at present, the youth in our country generally show strong patriotic enthusiasm and high national identity [3]. Because the governance experience of the Chinese government has attracted the unanimous praise of the international community, and we have contributed China's plan to the world. In front of the public health emergency of COVID-19, we young university students accepted the call of the Chinese Communist Party during the epidemic and devoted ourselves to voluntary activities of epidemic prevention. We personally feel and agree with our country's political system, political culture and political ideas. Young university students are now becoming the backbone of our society and we should vigorously promote patriotic acts in the whole society, guard against the influence of western "pseudo-human rights" on university students.

\subsection{Most University Students Do Not Attach Great Importance To The Ideological And Political Course}

The ideological and political theory course is the main way to strengthen political education in universities. However, now many universities students do not listen to lectures, skipping classes, mainly just for scores and improving the grade points. This is what students think of as "Easy-A course." Students are not enthusiastic about discussing ideological and political problems in class. And course assignments mainly rely on Baidu, Zhihu reference, no independent thinking. Students seldom take the initiative to understand the history of the development of political parties in our country and the existing policies.

\subsection{Some Universities Students Have Low Political Literacy}

Many university students do not understand the thought of socialism with Chinese characteristics, the road to socialism, the concept of government, the spirit of major conferences speech, more often through the network video, Baidu news to understand the national news, political literacy is less [4]. And their sense of responsibility is not strong, the chance of speaking freely is greater, like to share their personal life in micro-blog, WeChat, Tieba, Youyin and other online platforms, participating in the discussion of social hot spots, parroting the views of some political events, is easy to become a tool for illegal elements to propagate negative political news.

\section{MEASURES TO STRENGTHEN UNIVERSITY STUDENTS' SENSE OF POLITICAL IDENTITY IN POST- PANDEMIC TIMES}

\subsection{Enhance The Effective Governance Of The Government}

Party identity is the core of political identity. Therefore, to enhance the university students political identity, the party must constantly improve its own image. Whether the state and the government can protect and realize the individual rights and interests has become the primary premise of the people's political identity [5]. At present, China is guided by Xi Jinping's socialist ideology with Chinese characteristics and the Chinese characteristics with China's new era. For the government, it is necessary to improve the efficiency of administration according to law and governance, so as to serve the people 
wholeheartedly and let the majority of university students agree with the government's ruling concept. For university students, the party and the government should pay attention to their interests, such as employment, rental, security and other issues [6].

\subsection{Innovating The Ideological And Political Education Of University Students}

The education of political identity in university students is embedded in the system of ideological and political education, and the main channel of the political education is the ideological classroom. [7]Therefore, it is very important to pay attention to and innovate the course of ideological and political theory in cultivating students' political identity. First of all, teachers should change the theoretically educational oriented thinking system and guide students to discuss social hot topics consciously, promoting them to establish the correct political direction and value evaluation system. Let mainstream, authoritative, authentic voice affect students' thinking consciousness. Secondly, teachers should make full use of social networks such as WeChat and micro-blog to communicate effectively with contemporary university students to reduce intergenerational conflicts. Finally, the counselor should communicate with individual students who are not very patriotic, understand their state of mind, strengthen their political awareness.

\subsection{Improving University Students' Political Literacy}

Therefore, first of all, universities should strengthen the popularization of legal knowledge, understanding of the legal provisions, cannot think that the network world can be free in the law, to promote students to understand the law and to abide by the laws, do not create rumors, not to believe rumors, did not spread rumors. Secondly, universities can train students how to distinguish some fake news, more to pay attention to CCTV news, China daily and other official account message template report news, for unfavorable political information to the state can be reported. Finally, universities should guide students to understand the context of political events, understand the political history of each country and so on, improve students' ability to think and distinguish false.

\section{CONCLUSION}

Political identity is an important basis for maintaining long-term stability of the regime, which depends on the performance of the government. This is especially true in the post-epidemic era, with rising global unemployment and political and economic instability. As an important group, university students also deeply feel that the political performance of the country affects the political stability and their own life. For university students, employment opportunities, housing subsidies, preferential entrepreneurship policies are their immediate concerns, but also an important measure of their political identity. Therefore, we should properly solve these problems and innovate to strengthen the ideological and political education of university students.

At present, the political identity of university students is mainly embodied by value judgment and their own behavior. But the reality is that many university students have the defects of utilitarian political orientation and uncertain political belief. Therefore, we should strengthen the social mainstream ideology to guide them, stimulate their political enthusiasm and confidence, consciously resist decadent ideas, so as to cultivate correct political values. The political identity of university students is, in the final analysis, the recognition of the leadership and administration of the Communist Party of China. The international situation in the post-epidemic era is becoming increasingly treacherous. As young university students, we should keep on our own ideological and political consciousness to resist foreign "hedonism," "fake human rights doctrine," and "fake egalitarian culture." We need to rely more on our own willpower and resistance, and the conscious obedience of our political system, so as to implant a sense of political identity in our hearts.

\section{REFERENCES}

[1] Li Liaoning, Ni Shengming, New circumstances and new achievements of Ideological and political education in the post epidemic era. In: The Party Building and Ideological Education in Schools. 2020, pp. 4-8. DOI: https://doi.org/ 10.19865/j.cnki.xxdj.2020.15.001

[2] Gao Fei, Wang Dong, International situation in post epidemic era and China's countermeasures. In: Peace and Development. 2021, pp. 1-17+130+136142.

DOI: https://kns.cnki.net/kcms/detail/detail.aspx?FileNa $\underline{\text { me}=\text { HPFZ202101001 \&DbName }=\text { CJFQTEMP }}$

[3] Zhang Liangxun, Guo Yuankai. Research on Youth Political Identity and political participation. In , People's forum , 2020 , pp. 76-79. DOI: https://CNKI:SUN:RMLT.0.2020-24-024.

[4] Chen Ran. On the necessity and path of Strengthening College Students' political identity. In: Legal system and society, 2020, pp. 160-162. DOI: https://10.19387/j.cnki.1009-0592.2020.08.165.

[5] Xu Jialin, Zhang Qian. The formation premise of public political identity and national construction. In:Journal of Jiangsu University of administration, 2020, pp. 67-74 DOI: https://CNKI:SUN:JSXZ.0.2020-06-011. 
[6] Peng Jinfu, Research on the characteristics and strengthening path of College Students' political identity in the new era.In: Journal of Heilongjiang Institute of Teacher Development, 2000, pp. 91-93. DOI: https://CNKI:SUN:HLJB.0.2020-10-030.

[7] Xu Bingqing, On the realization path of College Students' political identity in the new era.In: Policy Research \& Exploration , 2020, pp. 51-52. DOI: https://10.16324/j.cnki.jcts.2020.08.025. 